\title{
Current development, non-formal vocational training of adults fosters employment opportunities in small scale industries
}

\section{Tolera Negassa}

College of Education and Behavioral Science, Arsi University, Ethiopia.

Accepted 31 July, 2019

\begin{abstract}
The purpose of this study was to investigate non-formal vocational training program in fostering selfemployment in small scale industries in Oromia Regional State. In the regional state, unskilled man power is one of the major problems at lower level despite the growth of small business. The small business usually requires people trained in short-term program. The short-term practice-based vocational training is given without taking feedbacks on the outcome and its contribution to the livelihood of people in the regional state. The study was conducted in five cities and five towns which have access to institutions offering practice-based vocational training. The study involved 1280 (640 males and 640 females) people organized in small scale enterprises. The data were collected using questionnaire with acceptable level of validity $(C V R>.55)$ and reliability $(r>.70)$. The descriptive survey data were analyzed in quantitative methods (frequency, percentage, reliability, t-test, and ANOVA). The result generally revealed that the program has created self-employment for thousands of unemployed adults seeking jobs although there is a difference in terms of gender, location, and fields of training. In conclusion, the non-formal training program in the region has to be given priority to reduce poverty, so as to enhance self-employment in vocational fields to support the government plan on agricultural lead industrialization program.
\end{abstract}

Keywords: Adult education, self-employment, non-formal vocational training.

E-mail: toleranegassad@gmail.com.

\section{INTRODUCTION}

Education is a process to enrich people's understanding of themselves and the world (Ozturk, 2001). It also acts as a primary agent of transformation towards sustainable development, increasing people's capacities to solve problems and transform their visions for society into reality (UNESCO, 1989). Scholars like Rogers (2004) distinguish three forms of education through which people acquire knowledge, skills and develop attitude. These are formal education, non-formal education, and the informal one, which is- incidental, and gained through life experience. Obviously, the technical and vocational education/training is shadowed under these three forms of education and referred to as formal vocational education, non-formal vocational education and informal vocational education (Haan, 2006). The intention of this study is not to deal with all the three forms of vocational training, but rather it focuses on the non-formal vocational training which is short-term and directly related to solve unemployment at lower level.

Bagnall (2007) pointed that in times and areas of high unemployment, the focus tend to be more on the development of individual capacity for self-employment through non-formal vocational training. Bagnall further asserts that community-based tradition in the non-formal training places more emphasis on providing vocational training for local community development, and enhancing the economic potential of the community members.

Formal training systems have been inefficient to address different groups, and the outcomes have been very expensive. It has also often been perceived as far from cost-effective (Hallak and Caillods, 1981; Fluitman, 1989). In the last decades, witness shows that the formal 
vocational training programmers had not designed programs to cater to the needs of the highly increasing number of uneducated people in developing countries (UNESCO, 1999). In a similar way, the practice-based vocational training was de-emphasized because of the expansion of formal education in the second half of the 1970s and 1980s (Hartog et al., 2001).

It was the mismatch between formal programs and the characteristics of disadvantaged people prompted the rapid diffusion of the practice-based vocational training in the education systems. Hence, non-formal vocational training is an emerging training initiative outside the formal system of vocational education. It represents the most recent initiative of non-formal kind, aimed at developing new institutional frames for skills development among people (Hoppers, 2006). Hoppers maintain that the objectives tend to be partly associated with national economic development, notably combat unemployment, reduce poverty and build national human resource capacity to improve a country's competitiveness in the market economy.

Haan (2006) indicates that there is a need to impart relevant skills to the informal entrepreneurs and workers. Skills development for informal micro-enterprises is crucial to withstanding the challenges posed by globalization and trade liberalization and also to continue to absorb hundreds of thousands of new job seekers every year. Similar study by UNESCO-UNEVOC (2004) shows that non-formal vocational training of adults provides technical expertise, which contributes to national prosperity and, by implication, promotes the well-being of individuals and families to fulfill their livelihood.

However, a study conducted by Kerre (1995) on nonformal vocational training identifies a list of the major challenges facing the development of vocational training of adults. These are low status, lack of market-oriented training, and shortage of human and financial resources. Besides, the impact of non-formal vocational training programs has received little research except, the studies on income and employment (Jespersen et al., 2008), and job-related skills (Fitzenberger and Volterb, 2007). These studies were based on the context of developed countries, the results were case dependent and were hardly generalized across countries, particularly to the under developing nations like Ethiopia. There could be also difference across training programs, needs, and models. Nafukho et al. (2005) affirm that the education of most African countries could not find the right solution to break poverty and move to the development of high level of thinking. Their priorities are to meet or fulfill their basic needs (food, shelter and clothing).

In the Ethiopian context, despite the expansion of vocational training program, accessibility of non-formal vocational training for unemployed adults, school dropout, employees in small scale enterprises, people living in rural and woman is still very limited (MoE, 2006). So far, much has not been done to enrich the academic literature, regarding the contribution of practice-based vocational training for self-employed people in the smallscale industrial sector, particularly for women, deprived of education and employment. The existing, empirical evidence and fact on the practice-based vocational training of the Technical Vocational Education and Training (TVET) sector-using data from the field survey were very limited. In Ethiopia, the existing experiences on the practice-based TVET program/ vocational training is hardly beyond reports of participation (Beyazen, 2008), establishment and expansion (Sandhaas, 2005). The studies did not investigate the dimensions of training, employability, market-related skill job and impact of the training on income of the trained people. It would be difficult to realize sustainable development without having alternative provision like non-formal vocational training approach that seems to give back up to the lower level skilled human power in agriculture-led industrialization system.

It can be said that non-formal vocational education/ training, in general, is needed outside of all main stream of the primary, secondary, teacher-training and university systems. Even more than formal institutions, practicebased vocational education institutions have a wide variety of functions geared towards different target populations. Since there are so many possibilities in practice-based training, it is helpful to delineate the priorities for special attention to the disadvantaged workforce youth and adults flourishing in the country.

Progressive adult education theory was assumed to guide this study as Rensburg and Landman (1984) states vocational and practical training betters adult's employability by focusing on problem solving skills development. The non-formal vocational training is designed for solving problems related to daily life activities. This theory is also reflected in the strategy set by the Ethiopian Ministry of Education. The Ministry has indicated that public and non-public non-formal vocational training providers shall offer employment-oriented training to various target groups. In particular, the program is accessible for school dropouts, unemployed people, and workers in the informal sector and micro-enterprises (MoE, 2006). The assumption is that the non-formal vocational training helps to increase access of creating self-employment opportunities, enhance competitiveness, improve quality of small-scale industrial products, increase income, improve the livelihood of target groups, and finally contribute to the overall poverty reduction and sustainable development in Ethiopia.

The present study, therefore, attempts to fill the knowledge gap in small-scale industries of developing countries. The study investigated the condition of practice-based vocational training in terms of offering participatory and job related training that could contribute to self-employment and thereby generate income in small-scale industries. In this study, the small-scale industries refer to nonagricultural self-employment in vocational skills activities, which are characterized by 4 to 10 workers. The industries involved in production and 
provision of services and have relatively small capital for investment (3000.00 ETB/150USD to 5000.00 ETB/250USD) beginning capital. The fundamental concern is to trigger ideas in investigating the contribution of the training on self-employed people working in smallscale industries that enhance the skill for productivity, increase earnings, and ultimately reduce poverty. To reach on valid conclusions, the following research objectives were set in this study.

The aims of this study are to:

- investigate the developmental feature of non-formal vocational training for self-employment.

- examine gender, and location differences in terms of training experience, self-employment and income.

- investigate training fields' differences in terms of training experience, self-employment and income.

\section{MATERIALS AND METHODS}

This study involves quantitative descriptive survey method to analyze the data collected from non-formal vocational trainees. Parkash (2005) asserts that descriptive survey help to describe phenomena employing data to determine the status and make more intelligent plans for improving the educational conditions.

\section{Area, population and samples of the study}

The study area: This study was conducted in Oromia Regional State. The selection of this region was made purposely based on its high population (over 27 million) (CSA, 2007). The area is characterized by high flow of commercial activities, high investments that needs trained people, and relatively has resources and number of skills training institutions, industries and exposure to the training of adult education practices as compared to other regions. It can be said that the region can fairly show the real situation of the practice-based vocational skills training program and its effect. The region has zones that are centrally located around the capital city of the country Addis Ababa that can easily open opportunities for adults to be trained, and work in vocational skills areas. Moreover, the researcher knows the region, the language and the culture of the region that could minimize difficulty in communication. The above justifiable reasons, the knowledge, and the informal relation with some of the skill training institutions in the region enabled the researcher to access the research area and collect information from sampled informants.

\section{Population}

The population for this study comprised adults who attended skills training program under the umbrella of
Technical Vocational Education and Training (TVET) institutions. Accordingly, a total of 2947 people trained in skills training working in different small-scale industry involved as self-employment were the target population. The study utilized 11 (eleven) cities and 12 (twelve) towns that have clustered TVET institutions, and 7 fields of skills training as the main focus area of the study. However, since it is difficult to include all the population, a minimum of $30 \%$ of the study population has been studied. McNeill and Chapman (2005) argue that the process of sampling involves selecting elements from the study population so that by carrying a study of the sample and having an understanding of the properties of the characteristics of the subjects of the sample, it is possible to generalize the properties to specific elements in the population.

\section{Samples}

In selecting sites, training field, and respondents, the study employed multistage sampling method as described below. In the selection, the researcher employed the probability sampling to infer the result to the population. In estimating the sample from the population, the researcher determined the level of confidence (95\%) assuming the samples are large enough to represent the population in all cases and the critical error or the probability that a significant difference will occur by chance $(p=.05)$. The inclusion of large sample may result in statistically significant conclusions and clear future study directions. It also optimizes the probability that a study will yield interpretable results and minimizes the sampling error.

\section{Selection of cities and towns}

In the region under study, there are 11 cities that have access to government established TVET institutions. The selection of cities and towns was based on equal allocation to maximize the probability of comparative analysis; to reduce risk in getting maximum number of respondents and generalize the results to the large population. Besides, the inclusion of such large sample may result in statistically significant conclusions and clear future study directions. In the same region, there are 155 vocational training institutions of which 94 are owned by the government, and 64 privately owned institutions. However, the researcher considered intuitions focusing on non-formal vocational skills training, since, the focus of the study is vocational skills area. The institutions are located in the 11 cities and the outskirts of the 12 towns mostly district 'Aanaa or Woreda' headquarters. In this case at least one government TVET institution is available in each of the cities and towns respectively. Therefore, from the 23 TVETs, samples of 10 institutions were selected using simple random sampling. 


\section{Selection of training fields}

The skills training offered at the training center for adults was based on market demands and flexibility the programs; however, this study selected training fields given consistently at all the selected centers for the last three years (2006 to 2009) in short-term. In the selection procedure a complete list of seven skills training fields which are more or less consistently given at all training institutions (Tailoring, Pottery, Construction, Embroidery (needlework), knitting, Metal Work, and Woodwork) were presented for selection. Accordingly, four training fields that were drawn in the first, second, third and fourth were selected using simple random lottery method. These are construction, metalwork, woodwork and tailoring training fields. Beyazen (2008) reported that the total hours for vocational fields are $463.92 \mathrm{~h}$, and the proportion $79.92 \mathrm{~h}$ $(20 \%)$ theory, and $384 \mathrm{~h}(80 \%)$ practice. Accordingly, all the selected training fields have similar training hours. The training is offered $20 \mathrm{hrs}$ per week for six months.

\section{Selection of respondents}

This study involved people who pass through short-term skills training in the identified fields for 6 months and join self-employment in small-scale industries/enterprise. In the selection process since each member has different background, the researcher collected pre-hand information about the participants through a person assigned to follow the industries at each cities and towns.

Accordingly, from 2947 people involved in the skills training, 1280 people involved in the non-formal vocational training were selected and included in the study. It could have been possible to determine the sample using sample size formals or table of sample size, however, this selection was made anticipating nonresponse minimization, improve the scarcity of the availability of trained people in the selected sites, and to make smaller the sampling error.

The allocation of the sample size was determined using multistage sampling approach (stratification using the proportion of the total sample required to the total population first, equal allocation to each cell and the simple random sampling). Hopkins (2008) notes that the safest way to ensure adequate sample size in descriptive survey study is identifying proportional representation of population to subgroups. The result of the proportion was found to be $1280(43 \%)$. To determine the sample size for each of the training field, each of the sub population or strata was calculated and adjusted to 160 in each cell. This was made to increase the number of participants in some towns. For each stratum, the sample size was assumed to be equally allocated to increase precision. The proportion by equal allocation could have been 40 for each of the cells. However, since the training characteristics are similar, to reduce the probability of missing respondents particularly in towns far from the center the number in each cell was adjusted to 32 , This number assumed to represent and reflect the characteristics of the sub populations for each of the stratum. In each cell, the percentage of the sample size is over $30 \%$, which is sufficient to represent the population.

The researcher had hoped to choose a sample of persons who have had skill training and directly engaged in small-scale industries. However, the researcher also identified ways that could help to minimize error to get the required respondents from the selected skills training area, and forced to develop procedures and criteria for selection to obtain the samples:

(a) First, assuming that the pattern of early career histories can influence the response of the respondents, in the analysis, restricting the sample to individuals in their first job after training was mandatory. To this end, the researcher has pooled only individuals who were in their first job after training. Obviously, training may facilitate access to a first job that may act as a steppingstone to other jobs for which the skills acquired in the training are no longer needed. (b) People were listed by their names in each site according to their gender and skill works. (c) At each site within each field the researcher drew an arbitrary starting name for both males and females by simple random method. The same procedure was followed until the required number of respondents was obtained in each field (Table 1).

\section{Instrument validation}

A study of vocational and technical training in relation to adults' education of various countries has been assessed to develop the instrument. The instrument employed in this study was a five point likert scale structured questionnaire measuring different types of constructs developed by the researcher.

To check the validity of the items, 18 Subject Matter Experts from the College of Education was involved. According to Lawshe (1975), if Content Validity Ratio (CVR) is below .49, the experts are more disagree than agree on item. An item with the Content Validity Ratio (CVR) below .49 was not considered to have acceptable content validity.

In order to keep dependable psychometric quality of the items used in this study, Factor Analysis Model (principal component) has been applied to organize items into factors and avoid an item that did not fit to the analysis. The factor analysis model (principal component) identified 3 major categories to measure trainees' reactions (training experience, self-employment and income generation as the major scale). The three categories were further divided into subscales. Under training experience 3 sub scales (participatory training, applicability, job related,) self-employment 2 subscales (job opportunity, and attitude towards skills work) and income generation 2 subscales income for basic needs 
Table 1. Distribution of respondents attended vocational skills.

\begin{tabular}{|c|c|c|c|c|c|c|c|c|c|c|c|c|c|c|c|c|c|}
\hline \multirow{3}{*}{ Study sites } & \multirow{3}{*}{ Total Popn } & \multicolumn{16}{|c|}{ Training fields } \\
\hline & & \multicolumn{4}{|c|}{ Construction } & \multicolumn{4}{|c|}{ Metal Work } & \multicolumn{4}{|c|}{ Wood Work } & \multicolumn{4}{|c|}{ Tailoring } \\
\hline & & $\mathbf{N}$ & $\mathbf{n}$ & $\mathbf{M}$ & $\mathbf{F}$ & $\mathbf{N}$ & $\mathbf{n}$ & $\mathbf{M}$ & $\mathbf{F}$ & $\mathbf{N}$ & $\mathbf{n}$ & $\mathbf{M}$ & $\mathbf{F}$ & $\mathbf{N}$ & $n$ & $\mathbf{M}$ & $\mathbf{F}$ \\
\hline Cities & 1,508 & 383 & 160 & 80 & 80 & 371 & 160 & 80 & 80 & 374 & 160 & 80 & 80 & 380 & 160 & 80 & 80 \\
\hline Towns & 1,439 & 365 & 160 & 80 & 80 & 350 & 160 & 80 & 80 & 368 & 160 & 80 & 80 & 356 & 160 & 80 & 80 \\
\hline Grand Total & 2,947 & 748 & 320 & 160 & 160 & 721 & 320 & 160 & 160 & 742 & 320 & 160 & 160 & 736 & 320 & 160 & 160 \\
\hline
\end{tabular}

* $N=2947, n=1280$

* N-population, $\mathrm{n}$ - sample, M- Male, and F- Female.

fulfillment and income for surplus) were identified. Cronbach's alpha $(r)$ was determined after factor analysis computation was made for the three sub scales of the training experience and the results were remarkable. Accordingly, the Participatory training approach $(r=.78)$ and the reliability of each item to the total was between $(r=.73$ to .78$)$; Applicability of the of the training was $(r=.73)$ and the reliability of each item to the total is between $(r=.64$ to .71$)$ and job related training is $(r=.80)$ and the reliability of each item to the total was between $(r=.70$ to .73). Job opportunity $(r \alpha=.76)$ and the reliability of each items to the total was between $(r \alpha=.71$ to.74); attitude towards skills work $(r \alpha=.74)$ and the reliability of each items to the total was between ( $r \alpha=.65$ to .75). Income for expenditure $(r \alpha=.76)$ and the reliability of each items to the total was between $(r \alpha=.71$ to. 78$)$; income for savings $(r \alpha=.73)$ and the reliability of each items to the total was between $(r \alpha=.64$ to .71). From the analyses all variables are above .70 , and as a result, included in the study as Nunnally (1978) affirms.

\section{Data analysis}

To reach a dependable result, the research objectives stated earlier were analyzed using the data gathered, and the following statistical instruments. The validity of the items of the questionnaire was subject to the judgment of content evaluation panel made up of 18 raters to establish Content Validity Ratio (CVR). In order to keep the psychometric quality of the items, factor analysis model has been applied to form factors measuring constructs of the study. Based on the factors or components identified, the level of internal consistency of the items was determined by Chronbach's Alpha Reliability Coefficient.

To compare the ratings given by the respondents from cities and towns on different occupational area t-test at alpha $=0.05$ level of significance was applied. The independent sample t-test is appropriate in comparing the difference between two means having the same number of subjects and tolerable variance involved in the study. Moreover, mean comparisons among the variables employed have been made using one-way analysis of variance (ANOVA). When running ANOVA, assumptions has been taken into account: Normality; all data is normally distributed and checked during factor analysis for each variables; homogeneity of variances in different levels of each independent variable were assumed to be equal; errors between cases are independent of one another and data for the dependent variable are interval scale and for the independent variables are categorical.

\section{RESULTS}

This part presents core of the study dealing with the results of the research. The data obtained is assessed, analyzed and presented quantitatively. The first part presents descriptive analysis of some background characteristics of respondents; the second part investigates the relationships between variables or measures, and results of the inferential analysis of data to investigate whether or not differences between groups exists significant or by chance factor. For each of the results, data was presented by figure, tables, followed by interpretations and clarifications.

The growing participation trend seems to imply that there is a tendency of change in attitude towards vocational skills and shows demand in the labour market. Females' involvement seems to be lower than females' counterparts are in the year 2007 to 2009 [2006 (Male 107, Female 109); 2007 (Male 155, Female 152); 2008 (Male 186, Female 179); 2009 (Male 197, Female 195)] (Figure 1). The participation is nearly increased by 


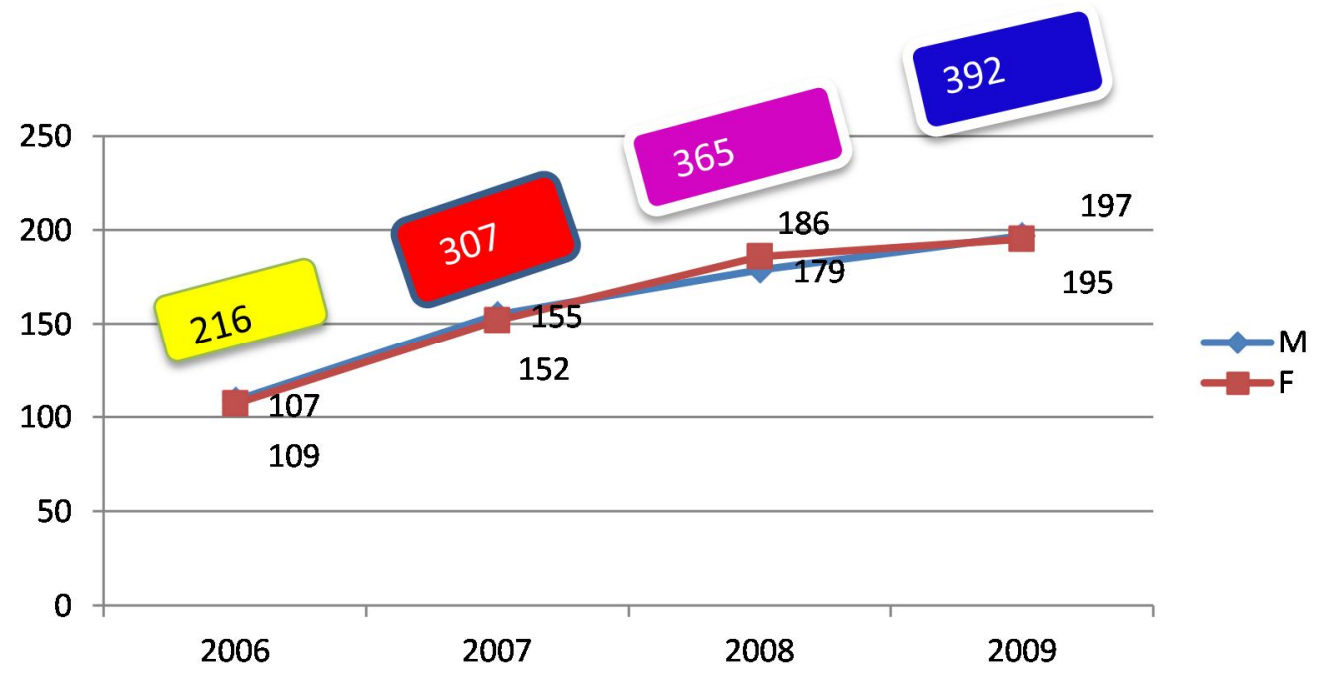

Figure 1. Non-formal vocational participation trend by year and gender.

45 to $50 \%$ each year. The consistent increase for both sexes in vocational skill area could be associated with the expansion of investment activities at different cities and towns. One of the significant assumptions could be associated to the mushrooming of building construction activities like building condominium houses, real state and private building at different cities and towns. As Mayoux (2005) repeatedly notes, traditionally, maledominated training courses (plumbing, metalwork, carpentry, etc.) have predominated in TVET in most countries.

Regarding age, the higher number of participants who were involved in the practice-based vocational training program and joined self-employment were people in their early adult (age 18 to 29, 49\%) as indicated in Table 2. This indicates that the program has an inclination to serve the early adults than the middle (age 30 to 39, $45.70 \%$ ) and late adults people (age 40 to $50,5.30 \%$ ).

To compare whether there exist difference between males and females on the subscale training experiences, self-employment and income, t-values has shown in Table 3.

In Table 3, analysis is made at alpha significance level of .05 statistical tests. An independent sample t-test is calculated on each of the grouping variables. The analysis identified that there is a statistically significant mean difference in gender pertaining to the training experiences sub scales participatory, and practical/applicability $t(1278)=3.87, p<.05$ and $t(1278)=$ $3.30, p<.05$ respectively. However, there is statistically non-significant difference on the variable of job-related training $t(1278)=.55, p>05$. In this test analysis, there is likely to reject the null hypothesis for participatory and practical training variables since the null hypothesis is in the direction of the alternative hypothesis. On the other hand, it is fail to reject the null hypothesis for job-related variables since it is not in the direction of the alternative hypothesis.

Table 2. Distribution of age by gender.

\begin{tabular}{lcccc}
\hline Age & Freq. & Percent & $\begin{array}{c}\text { Males } \\
\mathbf{n} \\
\boldsymbol{M}(\boldsymbol{S D})\end{array}$ & $\begin{array}{c}\text { Females } \\
\mathbf{n} \\
\boldsymbol{M}(\boldsymbol{S D})\end{array}$ \\
\hline Early adult (18-29) & 627 & 49.00 & 243 & 384 \\
& & & $25.20(2.97)$ & $25.25(2.74)$ \\
Middle adult (30-39) & 585 & 45.70 & $34.86(2.94)$ & $32.71(2.15)$ \\
& & & & \\
Late adult (40-50) & 68 & 5.30 & $43.00(1.18)$ & - \\
Total & 1280 & & 640 & 640 \\
\hline
\end{tabular}


Table 3. Training experience, self-employment, and income subscales by gender.

\begin{tabular}{|c|c|c|c|c|c|c|c|c|}
\hline Categories & Subscale variables & Gender & $\mathbf{n}$ & $\mathbf{M}$ & SD & t-value & df & Sig \\
\hline \multirow{6}{*}{ Training experience } & \multirow{2}{*}{ Participatory } & Males & 640 & 13.81 & 2.63 & \multirow{2}{*}{3.87} & \multirow{2}{*}{1278} & \multirow{2}{*}{.000} \\
\hline & & Females & 640 & 13.23 & 2.70 & & & \\
\hline & \multirow{2}{*}{ Practical/Applicability } & Males & 640 & 12.78 & 2.21 & \multirow{2}{*}{3.30} & \multirow{2}{*}{1278} & \multirow{2}{*}{.001} \\
\hline & & Females & 640 & 12.40 & 2.40 & & & \\
\hline & \multirow{2}{*}{ Job-related } & Males & 640 & 12.12 & 2.20 & \multirow{2}{*}{.55} & \multirow{2}{*}{1278} & \multirow{2}{*}{.582} \\
\hline & & Females & 640 & 12.06 & 2.10 & & & \\
\hline \multirow{4}{*}{ Self-employment } & Joh onnortunity & Males & 640 & 12.70 & 2.33 & \multirow{2}{*}{2.60} & \multirow{2}{*}{1278} & \multirow{2}{*}{.009} \\
\hline & JOD opportunity & Females & 640 & 12.35 & 2.45 & & & \\
\hline & \multirow{2}{*}{ Attitude towards skills work } & Males & 640 & 12.72 & 2.28 & \multirow{2}{*}{3.63} & \multirow{2}{*}{1278} & \multirow{2}{*}{.000} \\
\hline & & Females & 640 & 12.30 & 2.27 & & & \\
\hline \multirow{4}{*}{ Income } & \multirow{2}{*}{ Expenditure } & Males & 640 & 12.80 & 2.39 & \multirow{2}{*}{3.92} & \multirow{2}{*}{1278} & \multirow{2}{*}{.000} \\
\hline & & Females & 640 & 12.24 & 2.45 & & & \\
\hline & \multirow{2}{*}{ Savings } & Males & 640 & 12.12 & 2.38 & \multirow{2}{*}{-2.99} & \multirow{2}{*}{1278} & \multirow{2}{*}{.003} \\
\hline & & Females & 640 & 12.52 & 2.45 & & & \\
\hline
\end{tabular}

The mean difference is significant, $p<.05$.

Closer observation on the means indicated that females seem to have rated less in their involvement and share their own experiences than their male counterparts. Females taking their own responsibility in applying what they have learned in the contents of the training are slightly lower than males. Regarding the mean rating of applying the training into the world of work, one can see that males rated slightly higher than that of females. On job-related training, both rated in almost in a similar way but male seem to produce more than females.

The self-employment sub-scales show significant mean difference between males and females, $p<.05$. The analysis shows that there is a statistically significant mean difference in gender related to job opportunities, and attitude towards skills work $t(1278)=2.60, p<.05$ and $t(1278)=3.63, p<.05$ respectively. It reveals that it is likely to reject the null hypothesis in both variables since the null hypothesis is in the direction of the alternative hypothesis. In examining the mean of job opportunity sub scale, males seem to produce greater rating as compared to females rating.

The rating given by females to the sub scale attitude towards skills work is low compared to the variable job opportunity. This result seems to indicate that males have better attitude towards skills work than females. Though the two groups are different from each other, the low rating given to attitude compared to job opportunity by both sexes may have an effect on the sustainability, and gain better income particularly for females.

The income for expenditure/ fulfillment variable talks about the money gained from selling services of the skills work used to cover expenses attached to food and other necessary items to sustain in life. The analysis on the variables shows that there is a statistically significant mean difference between the two groups $t(1278)=3.92$, $p<.05$ and $t(1278)=-2.99, p<.05$, respectively. The groups are different in their reaction to the variables. As a result of the difference observed, the assumption that there is no difference seems to lead to reject the null hypothesis. Observation on means indicates that the mean for males is greater than that of their female's counterpart on expenditure.

The income for saving is more rated by females than males. The fact that the money is obtained from selling services of skills work invested for expenditure but less for saving. The saved money contributes to cover things other than used for daily expenses. For example, it could be used for community development, deposit in local saving account that could be used for building their own houses and purchase of durable equipments, etc.

In Table 3, it is observed that there is a statistically significant mean difference between cities and towns on the subscale applicability and job-related training variables $(M=12.93, S D=2.33), t(2,1278)=9.81, p<.05$ and $(M=12.63, S D=2.01), t(2,1278)=9.74, p<.05$ respectively. Cities respondents reported high regarding both applicability and job-related training as compared to the towns; whereas, towns' respondents show slightly more reaction to participatory training than the cities.

Table 4 reported that there is a statistically significant mean difference between cities and towns on the two subscales of self-employment. While the towns are limited to create job opportunities after the training, cities appear to be further encouraged in creating situations to attract investment. For job opportunity, the cities $(M=$ 13.02, $S D=2.39)$, are different from the towns $(M=$ $11.79, S D=2.37), t(2,1278)=9.37, p<.05$. On the other hand, rating on attitude towards skills training in cities 
Table 4. Training experience, self-employment, and income subscales by location.

\begin{tabular}{|c|c|c|c|c|c|c|c|c|}
\hline Category & Subscale variables & Location & $\mathbf{n}$ & $\mathbf{M}$ & SD & t-value & df & Sig \\
\hline \multirow{6}{*}{ Training experience } & \multirow[b]{2}{*}{ Participatory } & Cities & 640 & 13.53 & 2.62 & \multirow[b]{2}{*}{-.484} & \multirow[b]{2}{*}{1278} & \multirow[b]{2}{*}{.629} \\
\hline & & Towns & 640 & 13.60 & 3.13 & & & \\
\hline & \multirow{2}{*}{ Applicability } & Cities & 640 & 12.93 & 2.33 & \multirow{2}{*}{9.81} & \multirow{2}{*}{1278} & \multirow{2}{*}{.000} \\
\hline & & Towns & 640 & 11.63 & 2.41 & & & \\
\hline & \multirow{2}{*}{ Job-related } & Cities & 640 & 12.63 & 2.01 & \multirow{2}{*}{9.74} & \multirow{2}{*}{1278} & \multirow{2}{*}{.000} \\
\hline & & Towns & 640 & 11.50 & 2.14 & & & \\
\hline \multirow{4}{*}{ Self-employment } & & Cities & 640 & 13.03 & 2.39 & \multirow{2}{*}{9.37} & \multirow{2}{*}{1278} & \multirow{2}{*}{.000} \\
\hline & Jov opporiuminy & Towns & 640 & 11.79 & 2.37 & & & \\
\hline & \multirow{2}{*}{ Attitude towards skills work } & Cities & 640 & 13.21 & 2.20 & \multirow{2}{*}{11.07} & \multirow{2}{*}{1278} & \multirow{2}{*}{.000} \\
\hline & & Towns & 640 & 11.75 & 2.45 & & & \\
\hline \multirow{4}{*}{ Income } & Expenditure & Cities & 640 & 12.84 & 2.79 & \multirow{2}{*}{8.180} & \multirow{2}{*}{1278} & \multirow{2}{*}{.000} \\
\hline & & Towns & 640 & 11.51 & 3.02 & & & \\
\hline & \multirow{2}{*}{ Savings } & Cities & 640 & 12.11 & 2.99 & \multirow{2}{*}{4.457} & \multirow{2}{*}{1278} & \multirow{2}{*}{.000} \\
\hline & & Towns & 640 & 11.30 & 2.77 & & & \\
\hline
\end{tabular}

The mean difference is significant at 0.05 levels.

$(M=13.21, S D=2.20)$, is different from the towns $(M=$ $11.75, S D=2.45), \quad t(2,1278)=11.07, \quad p<.05$. In this analysis, people in the cities rated higher both on job opportunity and attitude towards skills work than people in towns.

The income for expenditure/basic needs fulfillment is substantially high among cities than towns. The fact that gaining high amount of return from selling skill services could be dependent on the condition of market and level of education. In the analysis above, $(N=1,280)$, the comparison on expenditure indicated cities $(M=12.84$, $S D=2.79)$, and towns $(M=11.51, S D=3.02, t(2,1278)=$ $8.180, p<.05$. The current observation around towns which is more or less rural and agrarian in character shows low rating both in expenditure and savings.
Regarding income for savings/surplus, the analysis showed that there is a significant difference between cities and towns. The comparison for savings revealed that cities $(M=12.11, S D=2.99)$, and towns $(M=11.3$, $S D=2.77), t(2,1278)=4.457, p<.05$. The rating given by people in cities is higher than that of towns. Moreover, the rating given to expenditure in cities and towns is higher than the savings characteristics.

The analysis in Table 5 indicates that there is a statistically significant mean difference for job-related variable. The comparison on means of job-related training showed that: Woodwork $(M=12.24, S D=2.13)$, Tailoring $(M=12.18, S D=2.19)$, Construction $(M=$ $12.16, S D=2.07)$, and Metalwork $(M=11.69, S D=2.19$, $F(3,1276)=4.37, p<.05$.

Table 5. Fields of skills by training experience.

\begin{tabular}{llccccc}
\hline Variables & & SS & df & M S & F & Sig \\
\hline \multirow{2}{*}{ Participatory } & Between group & 55.67 & 3 & 18.555 & 2.231 & .083 \\
& Within group & 10611.08 & 1276 & 8.316 & & \\
& Total & 10666.57 & 1279 & & & \\
& & & & & \\
Applicability & Between groups & 9.46 & 3 & 3.152 & .522 & .668 \\
& With groups & 7711.74 & 1276 & 6.044 & & \\
& Total & 7721.20 & 1279 & & & \\
& & & & & \\
Job-related & Between groups & 60.61 & 3 & 20.203 & 4.374 & \\
& Within group & 5893.61 & 1276 & 4.619 & & \\
& Total & 5954.22 & 1279 & & & \\
\hline
\end{tabular}

The mean difference is significant, $p<.05$. 
Further computation was conducted by Post-hoc analysis using Scheffe test to identify which of these training fields are significantly different from one other in their involvement of job-related training. The result has indicated that Metalwork $(M=11.69, S D=2.19,95 \% \mathrm{Cl}$ [11.92, 12.38]), is reported to be significantly different from Woodwork $(M=12.24, S D=2.13,95 \% \mathrm{Cl}[12.00$, 12.44]), and Tailoring $(M=12.18, S D=2.19,95 \% \mathrm{Cl}$ $[11.94,12.42])$ in rating job-related training variable. The effect size of job-related training is $R^{2}\left(r^{2}=1 \%\right)$ which is very small to do with the fields of training. It is observed that while woodwork respondents are better than tailoring and metalwork in their rating of job-related training, there are variations among respondents in their fields of skills.

Related to the creation of job opportunity, the calculated $F$-test analysis of variance suggested that there is a statistically significant means difference among the groups in rating job opportunity variable. In this comparison, job opportunity as rated by respondents of the different field reveals that Construction $(M=21.78$, $S D=4.72)$, Tailoring $(M=19.92, S D=4.78)$, Metalwork $(M=19.34, \quad S D=5.37)$, and Woodwork $(M=19.28$, $S D=4.85) F(3,1276), p<.05$. The result by Post-hoc analysis reveals that people in the construction industry $(M=21.78, S D=4.72,95 \% \mathrm{Cl}[21.25,22.13])$ shows statistically significant mean difference from metalwork $(M=19.34, S D=5.37,95 \% \mathrm{Cl}[18,88,20.45])$, woodwork $(M=19.28, S D=4.85,95 \% \mathrm{Cl}[18.75,19.82])$ and tailoring $(M=19.92, S D=4.78,95 \% \mathrm{Cl}[19.40$, 20.45]. The result indicated that the construction respondents are better in their job opportunity as compared to metalwork, woodwork and tailoring, and the difference is significant. The effect size of job opportunity is $R^{2}\left(r^{2}=4 \%\right)$ which is small number. It means that $4 \%$ of the variability in job opportunities that actually do with the fields of vocational skills.

The analysis on expenditure and savings suggested that there is statistically significant difference among the Groups (Table 6). The mean comparison for expenditure as follows: Construction $(M=12.63, S D=3.05)$, Metalwork $(M=12.22, S D=2.88)$, Woodwork $(M=$ 11.98, $S D=2.92)$ and Tailoring $(M=11.84, S D=3.01)$, $F(3,1276)=4,36, p<.05$. In similar manner the mean comparison for saving revealed that: Construction $(M=$ 12.49, $S D=2.91)$, Woodwork $(M=12.32, S D=2.98)$, Metalwork $(M=11.84, S D=2.55)$, and Tailoring $(M=$ $11.79, S D=2.80), F(3,1276), \mathrm{p}<.05$.

Table 6. Fields of skills by income.

\begin{tabular}{llccccc}
\hline Variables & & $\boldsymbol{S S}$ & $\boldsymbol{d f}$ & $\boldsymbol{M ~ S}$ & $\boldsymbol{F}$ & $\boldsymbol{S i g}$ \\
\hline \multirow{2}{*}{ Expenditure } & Between group & 115.06 & 3 & 38.35 & 4.36 & .005 \\
& Within group & 11231.13 & 1276 & 8.80 & & \\
& Total & 11346.19 & 1279 & & & \\
& & & & & & \\
\multirow{5}{*}{ Savings } & Between groups & 113.90 & 3 & 37.97 & 4.795 & .003 \\
& With groups & 10104.07 & 1276 & 7.92 & & \\
& Total & 10217.97 & 1279 & & & \\
\hline
\end{tabular}

The mean difference is significant, $p<.05$.

The result indicated that the construction respondents are better in their expenditure compared to tailoring, and the difference is significant. The effect size of the independent variables on the dependent variable expenditure is $R^{2}\left(r^{2}=1 \%\right)$ which is small. It indicates that $1 \%$ of the variability in expenditure is that actually to do with fields of vocational skills. In this analysis, where people in the construction industry are better in their expenditure, there is variation in respondents with each fields of vocational skills fields.

Moreover, the result of the comparisons made on saving has indicated that: Construction $(M=12.49, S D=$ $2.91, \mathrm{Cl}[12.15,12.79])$ is significantly different from Metalwork $(M=11.84, S D=2.55, \mathrm{Cl}[11.55,12.11])$ and Tailoring $(M=11.79, S D=2.80, \mathrm{Cl}[11.47,12.09])$. This shows that the construction respondents are different from metalwork and tailoring in terms of benefit and do a lot to increase their savings from selling services of their skills work. The effect size of the independent variables on the dependent variable saving is $R^{2}\left(r^{2}=1 \%\right)$ which is small. It means that $1 \%$ of the variability in saving is actually due to variations in fields of vocational skills. In this analysis, respondents in the construction industry were found to be better in their saving culture. There is wide variation in respondents with each field of vocational skills perspectives.

\section{DISCUSSION}

This study reveals that the growing participation trend seems to imply that there is a tendency of change in attitude towards vocational skills and shows demand in the labour market. There is a growing need for both male 
and females' involvement in vocational training. Haan (2006) assert that training opportunities serve as income generating programs for females in developing countries. Females' income was supplementary to the males, and females were not perceived as producers in their own right (Goodale, 1989). However, most vocational occupations remain strongly gender segregated (Ehrhart and Sadler, 1987). The writers put forward that, for several decades, females seemed to be "forgotten" not only from formal education but also from vocational trainings because they are less prepared for vocational occupations. On the contrary the females could otherwise benefit from a wide range of all education including technical skills that offer self-employment opportunity.

In the current context of Ethiopia development in general and Oromia Regional State in particular, location of respondents is diversified as development and urbanization appears to be moving from the centre to the peripheral areas. This can be observed in the current development of cities like Bishoftu, Adama, Nakamte, etc, where development and urbanization is fast growing compared to local towns like Gursum, Babile, Arjo, etc. This could have happened because of the fact that the places where to practice as entrepreneurs like, for example, construction of modern buildings, house building, carpentry, woodworks, metalwork, tailoring, brick production, etc. seems to be increasing in the cities than in the towns. This implies that the development of cities seem to have motivated and encouraged trained people to reflect real characteristics of adult learning than towns.

Consistent with this result, Bolaane et al. (2010) points out that, because of the development of cities, industries are highly attracting people from the surrounding rural. With regard to low ratings of trainees from town, a study by Umarik et al. (1999) reveals that the reasons behind the low trainees' practical competencies could include the relatively low technological basis of many vocational institutions.

In relation to this, Lee (2006) point that once people in small enterprises are given the required assistance, they are willing to make adequate investment and are able to improve their productivity in an effective and sustainable manner. Moreover, Haan (2006) also asserts that vocational skills training outcome is a means to an end, and not an end by itself, to increase access to rewarding employment, gradually to higher incomes and to reduce poverty.

The fields of skills training in the Ethiopian context are growing as compared to the last decade because of urbanization and investment (CSA, 2007). It is estimated that thousands of workers are engaged in the different components of construction industry of which the majority are adults, and a significant number of them are female as indicated both in the literature and in this survey. The fields such as metalwork, woodwork and tailoring sectors are yet other major areas of employment for more people living both in the cities and in the towns.

Similar to the present finding, a study made by Su and Feng (2008) states that technologies can provide a means through which people can improve lifelong learning skills and acquires additional competencies that they may require for purposes of employment. The point is that in these uncertain times in which technology is rapidly developing in all fields, particularly in vocational skills, institutions need to have the current course and assessment of trainees' attributes from the perspective of poverty reduction strategies. Haan (2006) asserts that vocational skills training outcome is a means to an end, and not an end by itself, to increase access to rewarding employment, gradually to higher incomes and to reduce poverty.

Although the training of adults is self-directed, however, related work can be done by scaling up the existing practices to the changing demands of market. This experience has to be well underlined which can be taken to other similar vocational training institutions. It is hoped that future research will further resume to develop a generalized measure for training effectiveness that focuses on the trainees of different ages, gender, and on geographically delineated areas. In this study, it has been revealed that in the non-formal vocational training designed for adults out of formal schools, and jobless people, the trainees' learned knowledge, skills and improves work behaviors through creating job opportunities and generating income from the services of skills work. In this regard, the training institutions benefited from the transfer of the skills and knowledge to the work environment. In order to ensure the quality of training, a number of factors such as materials and facilities, trained human power to supervise the training, standardizing the training without violating flexibility characteristics has to be considered, etc. This could intensify the connection and it brings about quality in nonformal vocational training.

\section{Conclusion}

This study has employed a large segment of sample, more standardized instruments followed by analysis that could give information in the area of practice-based vocational training situations. The lesson learned from the study has shown that the training intuitions were established to offer local and cost effective training for the poor adults and more or less related to the needs of the labour market particularly in the cities. As a result, the trend towards the development and expansion of the non-formal vocational training is increasing nearly by 40 to $50 \%$ from year to year. This reveals that the current provision of the non-formal vocational training has a tendency to motivate people to join self-employment. The program is contributing a lot in the struggle towards poverty reduction strategies for both male and female 
participants.

The low rating given by females compared to males in the ability to apply what has been learned into the world of work, in creating job opportunity and in molding attitude towards skills works have to be improved by the intervention of micro-cooperative offices through creating conducive environment like efficient access to credit, giving guidance and encouragement at work place, and through opening market opportunity for their products.

The study raveled that location as a factor, to attract investors through lobbing and creating awareness to facilitate skills service that would improve the livelihood of individuals in towns and district headquarters so that trained people could be more vibrant and beneficiaries in productive self-employment opportunities.

The construction worker is different from that of woodwork, metalwork and tailoring in benefiting of the training, for increase their skills and access in order to apply into the world of work.

Consequently, the respondents in the construction industry are better in receiving training related to the world of work, though there is a wide variation among respondents with each field of vocational skills perspectives.

It has to be noted that market-oriented training provisions require continually developing and renovating the existing situation; otherwise the question of competitiveness will not be answered. As it was strongly noted by Yunus that, if the poor are ready to lift themselves out of poverty, it's up to us to remove the institutional barriers we have created around them (Yunus, 2007). Because as investment is moving to the local people through strengthening provision of resources and assistance at district and local levels, access to reach large number of people, particularly rural settlement will be implemented.

The TVET agency of the regional state and the training institutions shall have plan to improve training delivery before the training owing to the significant relationship observed in terms of age, gender, location, exit from the training and in joining self-employment, applicability, relevance, that would improve job opportunity, attitude and income of the trained individuals.

A study of this type could have been carried out by each local training intuition internally but, in the present study, the researcher is external to the training institutions and the micro-cooperatives. This could limit the researcher not to monitor closely and provide periodic critical analysis. The present study employs free goal evaluation as a part of summative evaluation to investigate the success story of the non-formal vocational training and may have its own limitation and others may use different approaches can describe best.

In general, the survey demonstrated that regardless of age, gender, and geographical location an attempt were made to indicate the non-formal vocational training in the region has challenged unemployment of trained adults. It can be said that the program has re-stimulated the less educated, jobless poor people to participate in the practice-based vocational training, and helped to join selfemployment in the small-scale industrial sectors. To this effect, enhancing the quality of the program through further research and evaluation of the trainings and its production for market is one of the main tasks on the plate facing the region.

\section{REFERENCES}

Bagnall, R. G. (2007). Enhancing income generation through adult education: A comparative study. Brisbane: Australian Academic Press.

Beyazen, A. (2008). Non-formal TVET mapping survey: The case of Amhara, Oromia and Addis Ababa. Addis Ababa: Education Expert Center.

Bolaane, B., Chuma, J. M., Toteng, B., and Molwane, O. B. (2010). Tracer study on the employment of the vocational training graduates. Botswana: Home Grown (PTY) Ltd.

Central Statistical Agency (CSA) (2007). Summary report of the 2007 census. Addis Ababa Central Statistical Agency. Retrieved on 15 January 2011 from www.csa.gov.et/pdf/Cen2007_firstdraft.pdf.

Ehrhart, J. K., and Sadler, B. R. (1987). Looking for more than a few good women in traditionally male fields. Washington, DC: Association of American Colleges.

Fitzenberger, B., and Völter, R. (2007). Long-run effects of training programs for the unemployed in East Germany. Labor Economics, 14: $730-755$.

Fluitman, F. (1989). Training for work in the informal sector. Agenda item for the 1990s. Vocational Training Discussion Paper No.16. Geneva: ILO.

Goodale, G. (1989) Training for women in the informal sector in Fluitman, F. Training for work in the informal sector. Geneva:ILO

Haan, H.C. (2006). The training for work in the informal microenterprises sector. Fresh evidence from sub-Saharan Africa. Verij University of Amsterdam: Springer.

Hallak, J., and Caillods, F. (1981). Education, training and the traditional sector. Fundamentals of Educational Planning Series, No. 31. Paris: UNESCO/IIEP.

Hartog, J., Pereira, P. T., and Vieira, J. C. (2001). Changing return to education in Portugal during the 1998s and early 1990s: OLS and quintile regression estimator: Applied Economics, 33: 2021-2037.

Hopkins, G. (2008). Quantitative research design. Dunedin: University of Otago.

Hoppers, W. (2006). Non-formal education and basic education reform: A conceptual review. Retrieved on 12 Dec 2010 from IIEP web site: www.unesco.org/iiep.

Jespersen, S. T., Munch, J., and Skipper, L. (2008). Costs and benefits of Danish active labor market programmers. Labor Economics, 15: 859-884.

Kerre, B. (1995). Human resource development and vocational and technical education at Kenyatta University, Kenya. Nairobi: Kenyatta University.

Lawshe, C. H. (1975). A quantitative approach to content validity. Personnel Psychology, 28:563-575.

Lee, K. W. (2006). Effectiveness of government's occupational skills development strategies for small- and medium-scale enterprises: A case study of Korea. International Journal of Educational Development, 26: 278-294.

Mayoux, L. (2005). Learning and decent work for all: new directions in training and education for pro-poor growth in focus programme on skills, knowledge and employability. ILO: Geneva.

McNeill, P., and Chapman, S. (2005). Research method. 3rd Ed. London: Routledge.

Ministry of Education (MoE) (2006). Non-formal technical vocational education and training implementation framework. Addis Ababa: Ministry of Education. 
Nafukho, F., Amutabi, M., and Otunga, R. (2005). Foundations of adult education in Africa: African perspectives on adult education. South Africa Cape: David Langhan.

Nunnally, J. (1978). Psychometric Theory. New York: McGraw-Hill.

Ozturk, I. (2001). The role of education in economic development: a theoretical perspective. Journal of Rural Development and Administration, 33: 39-47.

Parkash, R. (2005). Methods of educational research. New Delhi: Ajay Verma.

Rensburg, C. J. J., and Landman, W. A. (1984). Notes on fundamental-pedagogic concepts - an introductorylorientation. Pretoria: N.G. Kerkboekhandel.

Rogers, A. (2004). Non-formal education: Flexible schooling or participatory education. London: Kluwer Academic Publishers.

Sandhaas, B. (2005). Adult education and development. Addis Ababa: International cooperation of the German adult education (IIZ/DVVI). East Africa Regional Office.

Umarik, M., Loogma, K., Hinno, K., Joons, S., and Ulikool, T. (1999). Assessment of practical training in VET as communication between the systems. Retrieved on October 2016 from http://oeiax4.nw.eenet. ee/esso4/30503.pdf.

UNESCO (1989). Education for all. Bangkok, New Delhi.

UNESCO (1999). Non-formal vocational training programmes for disadvantaged youth and their insertion into the world of work: towards a framework for analysis and evaluation. Paris: International Institute for Educational Planning.

UNESCO-UNEVOC (2004).Technical and vocational education and training and the "triple bottom line" of sustainable development. International Centre for Technical and Vocational Education and Training. Supplement 4 to the UNESCO-UNEVOC Bulletin, 9, 1-6.

Yunus, M. (2007). Creating a world without poverty: Social business and the future of capitalism. New York: Public Affair.
Citation: Negassa, T. (2019). Current development, non-formal vocational training of adults fosters employment opportunities in small scale industries. African Educational Research Journal, 7(3): 118-129. 